https://doi.org/10.17816/MAJ191S1148

\title{
MSCS ARE LOCATED IN THE PERINEURIUM OF THE RECIPIENT RAT AFTER ALLOTRANSPLANTATION INTO DAMAGED NERVE
}

\author{
E.S. Petrova, E.N. Isaeva, E.A. Kolos, D.E. Korzhevskii
}

Institute of Experimental Medicine, Saint Petersburg, Russia

\section{МСК ЛОКАЛИЗУЮТСЯ В ПЕРИНЕВРИИ КРЫСЫ-РЕЦИПИЕНТА ПОСЛЕ АЛЛОТРАНСПЛАНТАЦИИ В ПОВРЕЖДЕННЫЙ НЕРВ}

\author{
Е.С. Петрова, Е.Н. Исаева, Е.А. Колос, Д.Э. Коржевский \\ Отдел общей и частной морфологии, ФГБНУ «Институт экспериментальной медицины», \\ Санкт-Петербург
}

The gene and cell therapy, stimulating the regeneration of damaged nerves is currently under development. In these experiments mesenchymal stem cells (MSCs) are often used. The purpose of this study is to describe the localization and morphological features of mesenchymal stem cells derived from bone marrow after their allografting into the damaged rat nerve. MSCs of the bone marrow of Wistar-Kyoto rats were obtained from Transtechnology LLC (Head G.Polyntsev, Ph.D.). MSCs were cultured, identified and labeled by 5-bromo-2'-deoxyuridine (BrdU) in vitro. The sciatic nerve of adult Wistar-Kyoto rats $(n=12)$ was damaged (ligature, $40 \mathrm{sec}$ ), and the suspension of BrdU ${ }^{+}$MSCs $\left(5 \cdot 10^{4}\right.$ cells in $5 \mu \mathrm{l}$ per animal) was immediately transplanted into the damaged sciatic nerve. In a previous study, we have showed that some transplanted cells are located in the epineurium of the recipient's nerve. The perineurium of the recipient rats was studied in the present work. Perineurial cells have polygonal form, thin and flat cell nucleus and form several layers, the basement membranes being placed between them. Perineurium is characterized by the presence of occluding junctions that can be identified using anti-claudine antibodies. The use of antibodies to claudine allowed us to identify perineurium. Some $\mathrm{BrdU}^{+} \mathrm{MSCs}$ were found to survive 5-7 d following surgery and according to their localization and morphology became perineurium cells. Such extracellular matrix proteins as laminin, fibronectin, collagen are present in the perineurium. Apparently, the presence of these proteins creates a favorable biological environment for MSCs survival and for their differentiation towards perineurium cells. The results of the study confirm the mesenchymal origin of perineurium cells.

Keywords: МСK; периневрий; регенерация нерва.

В настоящее время для стимуляции регенерации поврежденных нервных проводников активно разрабатываются разные способы генной и клеточной терапии. В таких экспериментах наиболее часто применяются мезенхимные стволовые клетки (МСК). Целью данного исследования явилось описание локализации и морфологических особенностей мезенхимных стволовых клеток, полученных из костного мозга, после их аллотрансплантации в поврежденный нерв крысы. МСК крыс Вистар-Киото были получены в ООО «Транстехнологии» (руководитель к.б.н. Д.Г.Полынцев); клетки культивировали и метили бромдезоксиуридином (BrdU). Седалищный нерв взрослых крыс Вистар-Киото $(n=12)$ был поврежден путем наложения лигатуры $(40$ c). Суспензия меченных $\mathrm{BrdU}$ МСК была трансплантирована субпериневрально в нерв крысы-реципиента $\left(5 \cdot 10^{4}\right.$ клеток в 5 мкл на животное). Предыдущее исследование показало, что часть пересаженных клеток обнаруживается в эпиневрии нерва реципиента. В настоящей работе была изучена периневральная оболочка нерва крыс-реципиентов. Клетки периневрия имеют ряд отличительных особенностей: для них характерна многоугольная форма, уплощенные цитоплазма и ядро, они располагаются в оболочке в несколько слоев, между слоями находятся базальные пластинки, между клетками имеются клаудин-иммунопозитивные контакты. Применение антител к клаудину позволило нам идентифицировать периневральную оболочку. Было установлено, что часть пересаженных $\mathrm{BrdU}^{+} \mathrm{MCK}$ выживала через 5-7 сут после операции и по своей локализации и морфологии представляла собой периневральные клетки. Известно, что в периневрии в большом количестве представлены такие белки внеклеточного матрикса, как ламинин, фибронектин, коллаген и др. По-видимому, наличие этих белков создает благоприятную биологическую среду для выживания МСК и их дифференцировки в направлении клеток периневрия. Результаты исследования подтверждают мезенхимальное происхождение клеток периневрия.

Ключевые слова: MSCs; perineurium; nerve regeneration. 